Marianna Otmianowska ${ }^{1}$ (D) https://orcid.org/0000-0003-4253-5065

Muzeum Łazienki Królewskie

e-mail: marianna.otmianowska@gmail.com

Katarzyna Zajkowska ${ }^{2}$

Narodowe Archiwum Cyfrowe

e-mail: katarzyna.zajkowska@nac.gov.pl

\title{
o modernizacji serwisu internetowego archiwów państwowych. Szukajwarchiwach.gov.pl, czyli jak otwierać się na nowe grupy odbiorców?
}

\begin{abstract}
The Modernization of Polish State Archives' On-Line Service - Search the Archives: How to Invite New Users to the Service?
\end{abstract}

The article presents the most important conclusions from different surveys aimed at studying the search models, motivation and needs of search the archives service users. The UX survey used only the qualitative research methods and was conducted in two steps. First step consisted in individual in-depth interviews with surveyed persons and usability test on existing version of search the archives service. We surveyed a group of 15 persons. We met the same amount of surveyed persons during the second step consisting in creative workshops aimed at generating ideas on new ver-

${ }^{1}$ Marianna Otmianowska, obecnie pracująca w Muzeum Łazienki Królewskie, w latach 20162018 była Dyrektorem Narodowego Archiwum Cyfrowego i pomysłodawczynią projektu Modernizacja serwisu archiwów państwowych Szukaj w Archiwach.

${ }^{2}$ Katarzyna Zajkowska, kierownik projektu Modernizacja Szukaj w Archiwach [jest pracownikiem Narodowego Archiwum Cyfrowego].

${ }^{3}$ Artykuł jest kontynuacją, swoistym rozwinięciem, wystąpienia autorek, które miało miejsce podczas konferencji naukowej „Badania publiczności w instytucjach kultury” zorganizowanej w Krakowie przez Zakład Zarządzania Kulturą w Instytucie Kultury Polskiej Uniwersytetu Jagiellońskiego w dniach 11-12 kwietnia 2019 roku. 
sion of the service. The survey showed that service users can be divided into three groups: Viewers, searchers and specialists. Those groups differ in the way they use the service and the reason they use it, and the knowledge they have on the start. The conclusions from the survey where used during the service modernization process.

Keywords: user research, UX, user experience, archives, digitalization,

Słowa kluczowe: badania użytkowników, UX, user experience, archiwa, digitalizacja

Aby zrozumieć, jak szybko rozwija się sieć, pomyśl o chwilach, w których pracowałeś nad czymś tak intensywnie, że w końcu zabierało ci to całe dnie. Nie myślałeś wówczas właściwie o niczym innym. Wiedz zatem, że w tej chwili dziesiątki tysięcy ludzi pracują z takim samym zapałem nad stronami www. Niezliczone mnóstwo innych pracuje nieco wolniej. A wszystko to tylko dla ciebie.

[Babbie 2007: 559]

Zgodnie z obowiązującą Ustawą z dnia 14 lipca 1983 roku o narodowym zasobie archiwalnym i archiwach, archiwa państwowe są urzędami, a nie instytucjami kultury w ujęciu formalnym ${ }^{4}$. Archiwa państwowe, $\mathrm{z}$ tytułu rodzaju przechowywanych materiałów, a także ze względu na swoją społeczną odpowiedzialność, partycypują w szerokiej ofercie adresowanej wobec odbiorcy, a kształtowanej również przez szereg instytucji kultury, muzealnych czy bibliotecznych. Z pewnością także cyfrowy rozwój tychże instytucji stał się przyczynkiem do redefiniowania ich funkcji, a często także do odnajdywania obszarów współpracy. Określeniem, które należy w tym miejscu zacytować, jest GLAM, akronim angielskich słów galleries, labriries, archives, museums (galerie, biblioteki, archiwa, muzea). Patrząc z perspektywy misji i działalności instytucji GLAM, czyli miejsc gromadzących, zabezpieczających, popularyzujących i upowszechniających dobra kultury i dziedzictwa, troska o odbiorcę i użytkownika cyfrowej platformy archiwów państwowych wydaje się uzasadniona także w ramach szerszego dyskursu. Rafał Stępień, który analizował działalność edukacyjno-popularyzacyjną brytyjskich archiwów, zwrócił uwagę, że

Potrzeba kreowania wizerunku archiwum jako instytucji nowoczesnej i otwartej na potrzeby społeczne wydaje się coraz lepiej rozpoznana metodologicznie, a niewątpliwie została dostrzeżona i jest przedmiotem refleksji naukowej społeczności zawodowo związanej z dziedziną archiwalną [Stępień 2017: 125].

${ }^{4}$ Ustawa z dnia 14 lipca 1983 r. o narodowym zasobie archiwalnym i archiwach, t.j. Dz.U. 1983 nr 38 poz. 173, http://prawo.sejm.gov.pl/isap.nsf/download.xsp/WDU19830380173/U/D19830173Lj. pdf [odczyt: 20.02.2020]. 
Można sobie w tym miejscu zadać pytanie o znaczenie i rolę, jaką archiwa odgrywają w społecznych procesach kulturowych, ale także wśród świadomych, to znaczy szukających z własnej inicjatywy, odbiorców ich oferty. Stępień, dość szeroko ujmując zagadnienie, zwrócił uwagę, że promowanie dziedzictwa kulturowego i wzmacnianie wizerunku profesji archiwalnych może pozytywnie skutkować kształtowaniem wizerunku „miejsca nowoczesnego i przyjaznego dla potrzeb nauki i odpoczynku” [Stępień 2017: 126]. Wiele uwagi problematyce zarówno wizerunku archiwów, jak i ich funkcji popularyzatorskiej poświęcił także Hubert Mazur, zauważając, iż „Konsekwencją szeroko rozumianej informatyzacji archiwów i digitalizacji materiałów archiwalnych jest pojawienie się nowych multimedialnych form popularyzatorskich i edukacyjnych” [Mazur 2017: 82]. Także autorki artykułu podjęły się wcześniej szerszego spojrzenia na cyfrową rzeczywistość archiwów państwowych w ujęciu społecznej odpowiedzialności w dobie globalnej rewolucji informatycznej, opierając się na zdefiniowanej misji Narodowego Archiwum Cyfrowego, którą jest „budowanie nowoczesnego społeczeństwa, świadomego swojej przeszłości” [Otmianowska, Zajkowska 2017: 73]. Z pełnym przekonaniem warto rozwijać badania, a także refleksje związane $\mathrm{z}$ rozwojem usług archiwów państwowych jako instytucji służebnych wobec obywateli. Należy uwzględniać wszelkie formy komunikacji z odbiorcą, zarówno w wymiarze rzeczywistym, jak i wirtualnym, pamiętając, że te światy zawsze się będą przenikać. Swoistym obowiązkiem kadry zarządzającej i kierowniczej jest dążenie do antycypowania potrzeb użytkowników przez nieustanną komunikację, dialog oraz badania.

Paradygmat interakcjonizmu symbolicznego zakładającego, że „kluczowym zagadnieniem pozostaje funkcjonowanie znaczeń w kontekście społecznym, jaki przede wszystkim stanowi sytuacja wzajemnego oddziaływania ludzi” [Hałas 2006: 15] stał się dla Narodowego Archiwum Cyfrowego punktem wyjścia opracowania procesu działań przy modernizacji portalu szukajwarchiwach.gov.pl, zakładającego pracę $\mathrm{w}$ metodyce UX (user experience), obecnie często stosowanej w sektorze kreatywnym i związanym z informatyką. „Według interakcjonistów działania społeczne są kształtowane za pośrednictwem komunikacji, której prawidłowości socjologia powinna badać w pierwszej kolejności” [Hałas 2006: 15]. Jak pisał Herbert Blumer, jeden z ojców interakcjonizmu symbolicznego,

istota społeczeństwa tkwi w rozwijającym się procesie działania, a nie w ustalonej strukturze stosunków. (...) By zrozumieć społeczeństwo, trzeba je dostrzec i uchwycić w aspekcie działania, które o nim stanowi. Następnie takie działania należy ujmować i rozpatrywać w aspekcie działania połączonego, w którym odrębne linie działań dopasowują się i wiążą, a nie śledzić odrębne linie działań uczestników - obojętnie, czy będą to pojedynczy osobnicy, zbiorowości, czy organizacje [Blumer 2006: 267-268].

Takie refleksje naukowców pozwalają spojrzeć na stronę internetową - platformę udostępniającą dziesiątki milionów skanów materiałów archiwalnych w zupełnie 
nowym ujęciu. Elżbieta Hałas, opierając się na aspekcie wiedzy o obiektach, sposobie myślenia o nich oraz uwzględniając aspekt działania wobec nich, wyróżniła trzy wymiary znaczeń społecznych:

1. Wymiar poznawczy (społeczna wiedza o obiektach i sposób interpretacji znaczeń);

2. Wymiar komunikacyjny;

3. Wymiar dramaturgiczny, czyli tworzenie znaczeń we wzajemnym oddziaływaniu ludzi [Hałas 2006: 93].

Wszystkie te zaproponowane wyżej można próbować przenieść na płaszczyznę związaną z serwisem internetowym szukajwarchiwach.gov.pl, gdzie odbiorcy odnajdują, poznają i pogłębiają swoją wiedzę, gdzie zachodzi między internautami komunikacja, a wreszcie gdzie w jej konsekwencji interpretacje, wykorzystanie materiałów czy uzupełnianie informacji prowadzi często do nowych znaczeń. Te znaczenia odczytane z dzieł są także negocjowane przez różne osoby w działaniach, co potwierdza spostrzeżenia Blumera.

\section{Diag̉noza potrzeb}

Szukaj w Archiwach (www.szukajwarchiwach.gov.pl) to serwis archiwów państwowych, którego celem jest prezentacja metadanych i kopii cyfrowych materiałów archiwalnych. Serwis, uruchomiony w 2009 roku, został zaprojektowany i zbudowany przez Narodowe Archiwum Cyfrowe (NAC). Początkowo swoje zbiory opublikowały dwa archiwa: Archiwum Państwowe w Lublinie i Archiwum Państwowe w Poznaniu. Od tej pory liczba instytucji publikujących stale rosła, podobnie jak liczba użytkowników serwisu - od prawie 11,5 tysiąca w 2009 roku do prawie 700 tysięcy w roku 2018. Obecnie (luty 2020) w serwisie opublikowanych jest ponad 39 milionów skanów ze 101 instytucji, co czyni Szukaj w Archiwach największym serwisem do poszukiwań historycznych w Polsce 5 . Warto zaznaczyć, że archiwa państwowe gromadzą materiały (dokumenty, korespondencję, fotografie, materiały audiowizualne, mapy, plany i inne), które dokumentują wszelką działalność Państwa Polskiego, historię społeczną, gospodarczą, kulturalną i naukową Polaków w kraju i za granicą. Są to bogate zbiory, które mogą zainteresować szerokie grupy odbiorców. Szukaj w Archiwach, jako serwis archiwów państwowych, może stać się dla tych grup najbardziej wiarygodnym miejscem w sieci do poszukiwania autentycznych źródeł historycznych.

Serwis Szukaj w Archiwach jest skierowany do wszystkich obywateli, ze względu jednak na jego budowę - która opiera się na metodyce opracowywania materiałów

${ }^{5}$ Liczba z danymi dostępna na startowej stronie internetowej, https://szukajwarchiwach.gov.pl/ [odczyt: 26.02.2020]. 
archiwalnych - okazał się on w toku badań trudno dostępny dla użytkowników, którzy tej metodyki nie znają. Jak wskazują dane zgromadzone w Google Analytics ${ }^{6}$ oraz doświadczenia pracowników NAC - to spowodowało, że z serwisu przede wszystkim korzystają genealodzy, naukowcy (głównie historycy) oraz archiwiści. Największą grupę stanowią genealodzy również ze względu na fakt, że duża część opublikowanych materiałów to akta stanu cywilnego.

W związku z rozwojem technologii oraz coraz większymi potrzebami zarówno użytkowników, jak i archiwów Narodowe Archiwum Cyfrowe podjęło decyzję o modernizacji serwisu, której głównymi celami są:

- usprawnienie pracy w serwisie obecnych użytkowników;

- pozyskanie nowych grup odbiorców.

Wstępna analiza dokonana przez NAC, a następnie potwierdzona w badaniach serwisu, wskazuje, że podstawowym problemem jest różny poziom wiedzy osób korzystających z serwisu. Jak wspominamy wyżej, obecni użytkownicy wiedzą, jak opracowywane są materiały archiwalne, znają sieć archiwalną w Polsce i jej strukturę, znają zasadę pertynencji terytorialnej oraz zasadę proweniencji. Ponadto, jako specjaliści realizujący badania naukowe albo zawodowi genealodzy, poszukują konkretnych dokumentów. Te dwa czynniki mają znaczny wpływ na sposób poszukiwania przez nich materiałów archiwalnych i ich potrzeby względem serwisu.

Druga grupa odbiorców - roboczo nazwana przez nas „niespecjalistami” - nie ma wskazanej wyżej wiedzy. Poszukują oni intuicyjnie, a ponadto nie szukają konkretnych archiwaliów, a raczej różnych „starych dokumentów” w określonym temacie.

Początkowo - myśląc o nowej architekturze informacji serwisu - obawiałyśmy się, że połączenie tych dwóch różnych sposobów poszukiwania i potrzeb względem serwisu będzie niemożliwe, gdyż nie będziemy w stanie w pełni dopasować się do jednej i do drugiej grupy. Dlatego też zanim rozpoczęłyśmy projektowanie nowej odsłony serwisu, przeprowadziłyśmy kilkuetapowe badania jakościowe, których celem było szczegółowe poznanie modeli poszukiwawczych oraz potrzeb naszych użytkowników - obecnych i przyszłych.

Celem przeprowadzonych badań było poznanie odpowiedzi na pytania:

1. W jaki sposób obecni użytkownicy korzystają z serwisu?

2. W jaki sposób potencjalni użytkownicy obecnie poszukują materiałów archiwalnych w internecie? Z jakich serwisów korzystają i jakie napotykają problemy?

3. W jakim celu użytkownicy poszukują materiałów archiwalnych i jak je wykorzystują?

4. Jakie mają potrzeby i oczekiwania względem serwisów archiwalnych? Jakich funkcjonalności potrzebują, które ułatwią im pracę?

${ }^{6}$ Narzędzie firmy Google prezentujące ruch użytkowników w serwisach www. 


\section{Metody badawcze}

Projekt IT Narodowego Archiwum Cyfrowego „Modernizacja serwisu archiwów państwowych Szukaj w Archiwach" jest realizowany zgodnie z procesem tworzenia produktów nazywanym projektowaniem zorientowanym na użytkownika (User Centered Design - UCD) ${ }^{7}$. Jest to iteracyjne podejście do projektowania, które zakłada kilkakrotną weryfikację produktu z użytkownikiem i jego poprawianie. „Z góry zakłada się, iż w drodze tworzenia produktu mogą być podejmowane nie najlepsze decyzje projektowe, których naprawa jest możliwa tylko dzięki zderzeniu go z użytkownikiem końcowym" [Mościchowska, Rogoś-Turek 2015]. Weryfikacja odbywa się w drodze badań User Experience.

W procesie UCD zakłada się, że projektanci nie mają kompletnej wiedzy na temat potrzeb użytkowników i postrzegania przez nich produktu. Dlatego niezbędne jest przeprowadzenie badań, które pozwolą podjąć właściwe decyzje projektowe. Z takiego też założenia wyszło NAC i zleciło badania potrzeb użytkowników serwisu Szukaj w Archiwach, aby poznać swoich użytkowników, ich potrzeby i oczekiwania względem serwisu, co miało kluczowy wpływ na decyzje dotyczące funkcjonalności produktu. Badania zostały zlecone firmie UX, która specjalizuje się w tego typu pracach, zatrudnia badaczy UX i posiada odpowiednie doświadczenie oraz zaplecze badawcze (m.in. laboratorium, sprzęt i oprogramowanie do nagrywania wywiadów). Firma zaprojektowała i przeprowadziła badania, odpowiadała za rekrutację respondentów oraz opracowała raport, który zawierał również rekomendacje gotowych rozwiązań do zastosowania w serwisie. Doświadczenie badaczy miało znaczący wpływ na jakość przeprowadzonych badań oraz dobór odpowiednich respondentów. Ponadto wybrana firma dysponowała również własnym profesjonalnym laboratorium badawczym, w którym znajdowała się sala fokusowa ze sprzętem oraz oprogramowaniem do nagrywania wywiadów, a także sala podglądowa za lustrem fenickim, w której można było obserwować i analizować wywiady za zgodą respondentów.

Badania User Experience są badaniami jakościowymi, niekiedy wspieranymi badaniami ilościowymi. Wykorzystują one te same metody badawcze, co badania marketingowe, jednak ich cel jest inny.

Tradycyjne badania marketingowe skupiają się na tym, co ludzie myślą, mówią i czują oraz jak wpływa to na ich decyzje zakupowe. W dużej mierze bazują więc na deklaracjach respondentów. (...) Tymczasem badania user experience skupiają się na obserwacjach ludzkich zachowań i tego, w jaki sposób korzystają z produktów. W tym celu stosuje się metody bardziej jakościowe z mniejszą próbą respondentów, ale pozwalające uzyskać lepsze zrozumienie ludzkich zwyczajów i sposobów myślenia [Mościchowska, Rogoś-Turek 2015: 59-60].

7 Więcej na temat procesu jedna z autorek artykułu Katarzyna Zajkowska pisze w artykule: Jak otworzyć serwis na nowe grupy odbiorców, wykorzystując User Centered Design: Case study, 2018, https:// productvision.pl/ [odczyt: 26.02.2020]. 
Badania serwisu Szukaj w Archiwach zostały zrealizowane w dwóch etapach, w których wzięło udział 15 respondentów. Badani zostali podzieleni na dwie grupy. Pierwsza grupa - pięć osób - odpowiadała użytkownikom specjalistom, którzy korzystają z serwisu co najmniej dwa razy w tygodniu. Wśród nich znalazło się dwóch genealogów, dwóch archiwistów i naukowiec (historyk sztuki). Druga grupa (10 osób) była liczniejsza ze względu na większą różnorodność. Podczas rekrutacji firma badawcza wyłoniła:

- dwóch artystów, którzy przeglądają archiwalia w internecie, ponieważ poszukują inspiracji do swoich prac;

- dwóch dziennikarzy, którzy poszukują materiałów do swojej pracy;

- dwóch pasjonatów, którzy poszukują w archiwaliach materiałów związanych ze swoim hobby;

- jedną osobę, która poszukuje historii swojej rodziny;

- jednego studenta oraz jednego ucznia, którzy poszukują archiwaliów na potrzeby zajęć;

- jednego nauczyciela poszukującego materiałów na potrzeby zajęć z uczniami.

W ramach pierwszego etapu zostały przeprowadzone $\mathrm{z}$ respondentami indywidualne wywiady pogłębione oraz testy użyteczności obecnej wersji serwisu Szukaj w Archiwach w profesjonalnym laboratorium badawczym w Warszawie należącym do firmy badawczej w dniach 26 maja - 5 czerwca 2017 roku.

Celem indywidualnych wywiadów pogłębionych było poznanie przyzwyczajeń oraz oczekiwań badanych związanych z poszukiwaniem w internecie różnego rodzaju materiałów archiwalnych oraz sposobami ich wykorzystywania. W wyniku wywiadu poznałyśmy i zrozumiałyśmy między innymi typowe procesy poszukiwania archiwaliów oraz towarzyszące im emocje i problemy. Respondenci zaprezentowali swoje potrzeby względem serwisów prezentujących archiwalia. Kluczowy był dla nas kontekst użycia serwisów archiwalnych - jakie motywacje towarzyszą badanym podczas poszukiwań oraz w jakim celu poszukują tego rodzaju materiałów.

Podczas testów użyteczności serwisu Szukaj w Archiwach respondenci mieli do wykonania dziewięć zadań. Zadania zostały dobrane tak, aby pozwalały wykorzystać kluczowe funkcjonalności obecnej wersji serwisu. Respondenci głośno prezentowali swoje wrażenia, mówili, co im się podoba oraz co sprawia im trudności. Testy zadaniowe pozwoliły nam wyłapać błędy użyteczności serwisu, dzięki czemu nie powieliłyśmy ich w modernizowanej wersji. Poznałyśmy również rozwiązania, które ułatwiły respondentom poszukiwanie materiałów.

Niecałe dwa tygodnie później (13 czerwca 2017 r.) wszyscy respondenci zostali ponownie zaproszeni na wspólne jednodniowe warsztaty kokreacji. Celem warsztatów było wspólne generowanie pomysłów dotyczących nowej wersji serwisu, opartych na potrzebach i doświadczeniach wszystkich uczestników spotkania, a więc uwzględniających różne perspektywy. W rezultacie uzyskałyśmy listę niezbędnych i dodatkowych funkcjonalności i cech serwisu archiwalnego. 
Podczas warsztatów dodatkowo wykorzystałyśmy metodę sortowania kart. Uczestnicy spotkania mieli za zadanie uporządkować w grupy różnego rodzaju materiały archiwalne, a następnie nazwać każdą z grup. W ten sposób poznaliśmy sposób myślenia użytkowników na temat kategoryzacji archiwaliów, który - jak się okazało - jest odmienny od kategoryzacji zgodnej z metodyką opracowywania materiałów archiwalnych.

Finałem warsztatów było budowanie w grupach prototypów „Archiwum przyszłości” przy użyciu różnych materiałów plastycznych. W ten sposób zespoły zaprezentowały namacalną reprezentację pomysłów rozwiązań nowego serwisu i wytłumaczyli, w jaki sposób zaproponowane funkcje i udogodnienia moga działać. Dzięki zastosowaniu tej techniki badani wyszli poza obecne rozwiązania i zaproponowali niedostępne obecnie, nowe sposoby poszukiwania i korzystania z materiałów archiwalnych. Badaczom i projektantom pozwoliło to lepiej zrozumieć potrzeby użytkowników.

\section{Najważniejsze wnioski $z$ badań}

W wyniku badań Narodowe Archiwum Cyfrowe uzyskało od firmy badawczej szczegółowy raport $^{8}$ prezentujący sposoby poszukiwania materiałów archiwalnych, motywacje i cele, jakie towarzyszą użytkownikom podczas poszukiwania archiwaliów, obecne problemy związane z poszukiwaniem oraz potrzeby użytkowników względem serwisów prezentujących zasoby archiwów i innych instytucji i ich pożądane cechy oraz funkcjonalności.

Badania pokazały, że użytkowników serwisów archiwalnych można podzielić na trzy grupy, nazwane w raporcie przez firmę badawczą: oglądaczami, poszukiwacza$m i$ i specjalistami. Grupy te różni sposób i cel korzystania z serwisów archiwalnych oraz wiedza, z jaką rozpoczynają poszukiwania.

Oglądacze to użytkownicy, którzy lubią przeglądać zawartość serwisu archiwalnego, ale nie poszukują konkretnych materiałów archiwalnych. Lubią serwisy, w których od razu dostępne są skany, które mogą przeglądać. Podobnie korzystają z serwisów archiwalnych poszukiwacze. Zależy im na dostępie do dużej liczby skanów do przeglądania, szukają jednak konkretnych materiałów. Dlatego też poszukiwacze prędzej skorzystają z wyszukiwarki, wpisując ogólne hasło wyszukiwawcze. W związku z tym, że sposób eksploracji serwisu przez te dwie grupy jest podobny, w procesie projektowym zostały potraktowane jako jedna grupa użytkowników.

${ }^{8}$ Z wynikami badań można zapoznać się w Narodowym Archiwum Cyfrowym w trybie wniosku o dostęp do informacji publicznej zgodnie z Ustawą z dnia 6 września 2001 r. o dostępie do informacji publicznej (Dz.U. 2001 nr 112 poz. 119 ze zm.; t.j. Dz.U. 2016 poz. 1764). 
Co w największym stopniu odróżnia ogladaczy i poszukiwaczy od specjalistów, to wiedza, z jaką przystępują do poszukiwania materiałów archiwalnych. Specjaliści (głównie naukowcy i genealodzy) znają metodykę opracowywania materiałów archiwalnych, wiedzą, jak wygląda sieć archiwalna w Polsce, wiedzą na jakiej zasadzie materiały trafiają do danego archiwum, często również znają praktykę opisywania archiwaliów. Ta wiedza znacznie ułatwia im poszukiwania archiwaliów w archiwach państwowych. Są to użytkownicy, którzy w większości w związku z pracą zawodową poszukują bardzo konkretnych dokumentów czy innych materiałów archiwalnych. Jak pokazały badania, osoby te, korzystając z serwisu Szukaj w Archiwach, rzadko posługują się wyszukiwarką. Wykorzystując posiadaną wiedzę, przeglądają zasoby konkretnych archiwów. W pierwszej kolejności wchodzą na podstronę archiwum, o którym wiedzą, że dane materiały będą się w nim znajdować. Następnie przeglądają zespoły, serie i jednostki archiwalne z zasobu tego archiwum. Jak można zauważyć, badania wykazały, że mamy do czynienia z dwoma skrajnymi modelami poszukiwania archiwaliów i eksploracji serwisów archiwalnych.

Po pierwszych publicznych prezentacjach raportu pojawiły się wątpliwości, czy próba połączenia potrzeb dwóch różnych grup użytkowników nie spowoduje utraty naukowego charakteru serwisu na rzecz stworzenia ogólnoinformacyjnego portalu. Takie pytanie wybrzmiało między innymi podczas rozmowy jednej z autorek niniejszego artykułu opublikowanej w magazynie „IT w Administracji”:

serwis nadal będzie prezentować zasoby archiwów państwowych i to jest jego podstawowe zadanie. Obecni użytkownicy będą mogli korzystać z serwisu tak jak do tej pory, ale zyskają nowe udogodnienia (...). Przebudujemy jednak interfejs, aby był bardziej intuicyjny i przyjazny dla nowych odbiorców [Zajkowska, Kornak 2018: 27].

$\mathrm{W}$ ten sposób w jednym serwisie połączymy potrzeby dwóch różnych grup.

Ponadto warto zwrócić uwagę na inne wnioski, jakie pojawiły się podczas badań, a które są charakterystyczne nie tylko dla użytkowników serwisu archiwów państwowych, ale również innych serwisów prezentujących w sieci narodowe dziedzictwo. Pierwszy z nich - charakteryzujący oglądaczy i poszukiwaczy - to oczekiwanie, że zdigitalizowane zasoby serwisu będą dostępne od razu na stronie głównej, bez konieczności wyszukiwania. Użytkownicy oczekują, że po wejściu do serwisu od razu dostaną wiele skanów, które będą mogli przeglądać aż coś przykuje ich uwagę. Po wejściu na stronę konkretnego materiału chcieliby uzyskać podpowiedzi innych podobnych materiałów, dzięki czemu będą mogli „wędrować po serwisie”: „Idę takim łańcuszkiem, jak na YouTube, coś nam podpowie, coś nas zainteresuje i trzy godziny z głowy"'.

${ }^{9}$ La Wonderlab na zlecenie Narodowego Archiwum Cyfrowego [2017], Badania potrzeb użytkowników oraz testy serwisu Szukajwarchiwach.gov.pl. Raport, Warszawa. 
Wszyscy użytkownicy preferują krótkie, konkretne, hasłowe opisy niż rozbudowane i narracyjne. Można wywnioskować, że dzisiejszego użytkownika internetu charakteryzuje myślenie tagami. Tagi - krótkie konkretne hasła charakteryzujące źródła - pozwalają szybciej zorientować się, czego dotyczy dany materiał, dzięki czemu w krótszym czasie użytkownik jest w stanie zapoznać się z większą liczbą rekordów i szybciej znaleźć to, czego poszukuje. Ponadto tagi są aktywnymi linkami. Jeśli użytkownik znajdzie hasło, które odpowiada jego poszukiwaniom, po kliknięciu w nie zostanie przekierowany do innych materiałów, które mogą go zainteresować. Użytkownicy serwisu Szukaj w Archiwach deklarowali gotowość samodzielnego dodawania tagów przy materiałach, co znacznie ułatwi poszukiwania innym odbiorcom serwisu.

Tagowanie społeczne oraz inne formy zaangażowania użytkowników we współtworzenie serwisu to kolejny istotny wniosek z badań. Odbiorcy oczekują funkcjonalności, które pozwolą im uczestniczyć w rozwoju serwisu i współtworzyć treści, dzięki czemu stworzą zaangażowaną, współpracującą społeczność wokół serwisu. Oprócz tagowania gotowi są dodawać opisy do jeszcze nieopracowanych materiałów, tworzyć własne kolekcje tematyczne/galerie skanów czy zgłaszać propozycje poprawek w opisach.

Warto zaznaczyć, że raport z badań zawiera również wiele wniosków i rekomendacji dotyczących wprowadzenia konkretnych funkcjonalności czy innych rozwiązań na stronie www, gdyż taki między innymi był cel zlecenia badań. Nie prezentowałyśmy jednak szczegółowo wniosków z raportu zarówno podczas prezentacji, jak i w niniejszym artykule. Chciałyśmy pokazać, sposoby myślenia, motywacje i oczekiwania użytkowników, które w naszej opinii są charakterystyczne dla odbiorców wszystkich serwisów prezentujących zasoby dziedzictwa narodowego.

Wnioski z badań zostały wykorzystane do stworzenia nowej wersji serwisu archiwów państwowych, który prezentuje ich zasoby. Dzięki badaniom w jednym serwisie zostały połączone odmienne potrzeby specjalistów - naukowców i genealogów - oraz poszukiwaczy amatorów. Zmodernizowana wersja serwisu została zbudowana z wykorzystaniem modeli poszukiwania użytkowników, które zostały zidentyfikowane podczas badań. Serwis uwzględnia większość funkcjonalności i cech, których oczekiwali odbiorcy. Poniżej prezentujemy stronę główną poprzedniej i zmodernizowanej wersji serwisu (fotografia 1,2).

Badania miały charakter jakościowy i uwzględniały analizę małej próby ( 15 badanych). Podczas analizy nie brano pod uwagę parametrów ilościowych i nie stosowano wnioskowania statystycznego. Wynika to z tego, że badania User Experience są nastawione na poznanie zachowań, zwyczajów, doświadczeń i potrzeb odbiorców produktu oraz sposobów interakcji z produktem. Badaczy interesuje „jak?” i „dlaczego?” badany tak się zachowuje, niż „ile?”. Doświadczenia badaczy User Experience pokazują, że jakościowe badania doświadczeń użytkowników pozwalają wychwycić ok. 80\% zwyczajów, potrzeb czy błędów użyteczności serwisów www. 


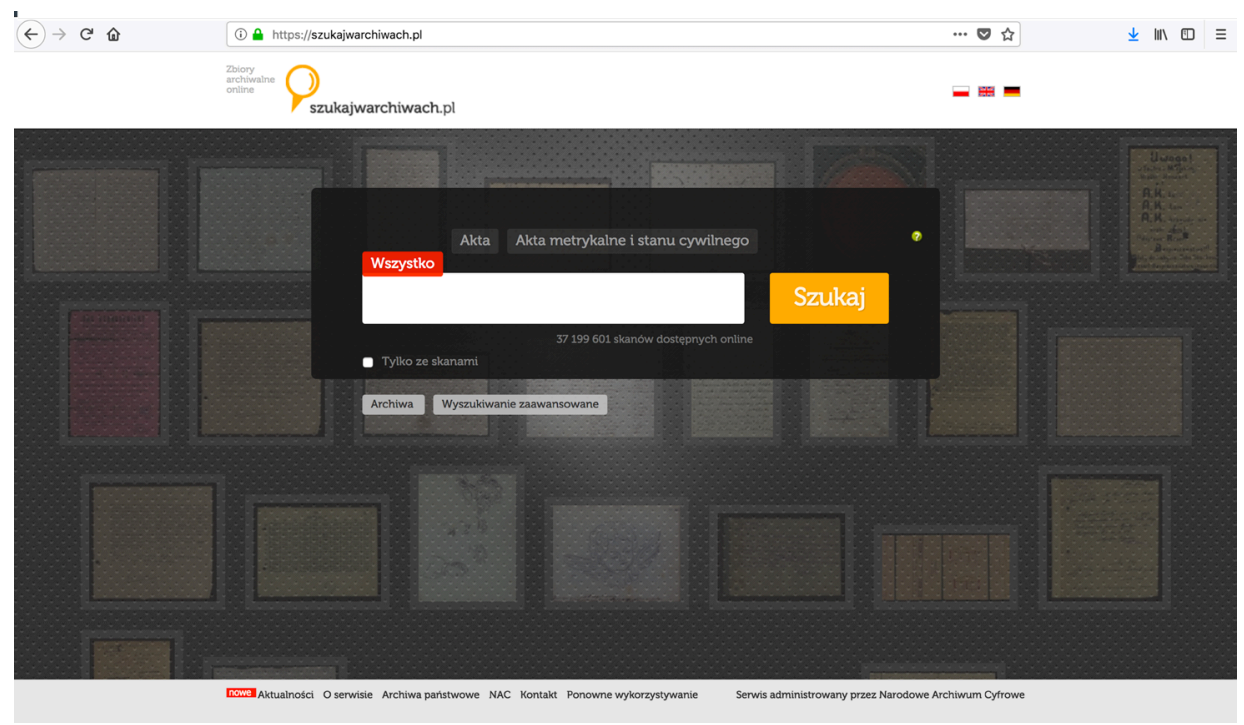

Fotografia 1. Strona główna serwisu Szukajwarchiwach.pl - zrzut ekranu z 28 maja 2019

Źródło: Szukajwarchiwach.pl [odczyt: 28.05.2019].

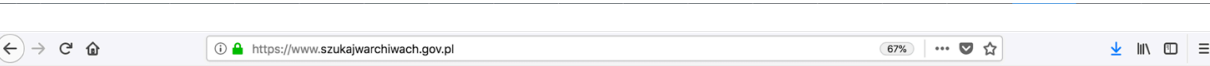
(D) Szukaj w Archiwach

Szukaj w Archiwach to zbiory archiwalne on-line
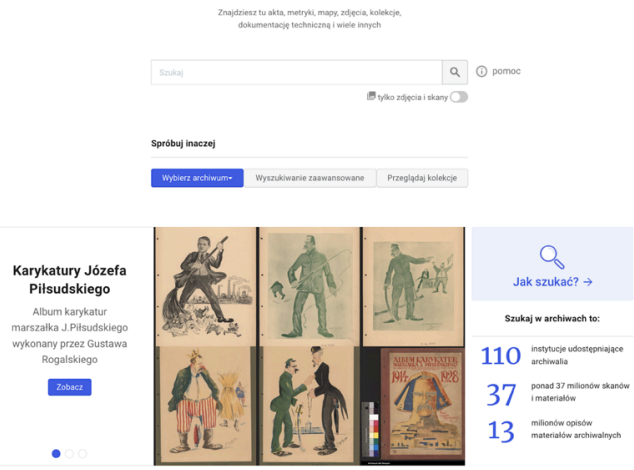

Fotografia 2. Projekt strony głównej Szukajwarchiwach.gov.pl po modernizacji

Źródło: Materiały projektowe Narodowego Archiwum Cyfrowego. 
Podejście User Centered Design zakłada weryfikację efektów pracy nad produktem w kilku etapach. Dlatego też NAC przeprowadziło jeszcze dwukrotnie badania z użytkownikami w formie testów użyteczności: najpierw prototypu serwisu, a następnie gotowego produktu - jeszcze przed uruchomieniem. Po poprawkach nowa odsłona szukajwarchiwach.gov.pl została oddana dla publiczności w czerwcu 2019 roku $^{10}$.

Warto jeszcze wspomnieć, że w trakcie realizacji projektu została odnotowana potrzeba wykorzystania materiałów znajdujących się w serwisie do działań edukacyjnych. Archiwalia pochodzące $\mathrm{z}$ archiwów państwowych mają duży potencjał dydaktyczny jako najbardziej wiarygodne źródła historyczne. W tym celu powstały założenia dodatkowego modułu w serwisie Szukaj w Archiwach, roboczo nazwanego Strefą Edukacyjną. W 2018 roku NAC zleciło badania, których celem była weryfikacja założeń Strefy Edukacyjnej i ustalenie jej ostatecznego kształtu. Podczas badań zostały przeprowadzone spotkania z nauczycielami różnych poziomów nauczania oraz edukatorami archiwalnymi i muzealnymi, studentami i uczniami szkół podstawowych oraz liceów. Raport z badań także jest dostępny w NAC. W chwili oddawania artykułu do druku Strefa Edukacyjna była w fazie analizy i planowania prac programistycznych.

\section{Podsumowanie}

Cytowany na początku artykułu Earl Babbie, interpretując określenie „interakcjonizm symboliczny", zauważył, że:

Mead wykazywał też wyjątkowe zainteresowanie rolą komunikowania się w relacjach międzyludzkich. Sądził, że większość interakcji obejmuje proces, w którym jednostki osiągają wzajemne porozumienie poprzez użycie języka i innych podobnych systemów, stąd termin symboliczny interakcjonizm [Babbie 2007: 60].

George Herbert Mead (1863-1931) nie mógł przewidzieć komunikacji w cyberprzestrzeni, warto jednak $w$ tych nowych możliwościach upatrywać zarówno wartości, jak i wyzwań. Będąc świadkami i jednocześnie uczestnikami cyfrowej rewolucji, stajemy się także w pewnym stopniu odpowiedzialni za jej formę, w tym także między innymi za mechanizmy komunikacji między użytkownikami. Bez ciągłego, powtarzalnego badania ich potrzeb, oczekiwań, obaw, definiowanych przez nich zagrożeń najprawdopodobniej trudno będzie doprowadzić do wzajemnego porozumienia pomiędzy archiwami a ich użytkownikami. Przyjmując opisane wyżej formy i tryby pracy, Narodowe Archiwum Cyfrowe wypełnia Strategię na lata 2017-2019,

${ }^{10}$ Zachęcamy do korzystania z serwisu i wysyłania do NAC swoich opinii i uwag. Chcemy stale ulepszać serwis, dlatego każda opinia jest dla nas cenna. 
realizując trzy podstawowe jej cele: (1) zapewnianie nowoczesności archiwów; (2) budowanie tożsamości wyrastającej z pamięci; oraz (3) dbanie o przejrzystość i ciągłość państwa ${ }^{11}$.

\section{Bibliografia}

\section{Publikacje}

Babbie E. (2007), Badania społeczne w praktyce, tłum. W. Betkiewicz, Warszawa: Wydawnictwo Naukowe PWN.

Blumer H. (2006), Impikacje socjologiczne myśli George’a Herberta Meada, [w:] A. Jasińska-Kania A. et al.. (red.), Współczesne teorie socjologiczne, t. 1, Warszawa: Wydawnictwo Naukowe Scholar, s. 262-271.

Hałas E. (2006), Interakcjonizm symboliczny. Społeczny kontekst znaczeń, Warszawa: Wydawnictwo Naukowe PWN.

Mazur H. (2017), Wystawy wirtualne archiwów państwowych - wybrane zagadnienia, [w:] V. Urbaniak (red.), Educare necesse est - powrót do źródeł. Przykłady dobrych praktyk edukacyjnych, Warszawa: Archiwum Państwowe w Warszawie, s. 81-102.

Mościchowska I., Rogoś-Turek B. (2015), Badania jako podstawa projektowania User Experience, Warszawa: Wydawnictwo Naukowe PWN.NAC (2017), Badania potrzeb użytkowników oraz testy serwisu szukajwarchiwach.gov.pl. Raport, Warszawa: La Wonderlab na zlecenie Narodowego Archiwum Cyfrowego.

NAC (2017), Strategia NAC na lata 2017-2019, https://www.nac.gov.pl/instytucja/misja-nac-2/ [odczyt: 20.05.2019].

Otmianowska M., Zajkowska K. (2017), Szukaj w archiwach jako źródło, [w:] V. Urbaniak (red.), Educare necesse est - powrót do źródeł. Przykłady dobrych praktyk edukacyjnych, Warszawa: Archiwum Państwowe w Warszawie, s. 73-80.

Stępień R. (2017), Działalność edukacyjno-popularyzacyjna archiwów brytyjskich na przykładzie kampanii Explore Your Archive, [w:] V. Urbaniak (red.), Educare necesse est - powrót do źródeł. Przykłady dobrych praktyk edukacyjnych, Warszawa: Archiwum Państwowe w Warszawie, s. 125-134.

Zajkowska K. (2018), Jak otworzyć serwis na nowe grupy odbiorców wykorzystując User Centered Design. Case study, https://productvision.pl/ [odczyt: 26.02.2020].

Zajkowska K., Kornak K. (2018), Otwieramy serwis na nowych użytkowników, „IT w Administracji”, nr 12 (133).

${ }_{11}$ Wersja skrócona Strategii NAC na lata 2017-2019, https://www.nac.gov.pl/instytucja/misja-nac-2/ [odczyt: 20.05.2019]; pełna wersja dostępna jest w Narodowym Archiwum Cyfrowym. 


\section{Akty prawne}

Ustawa z dnia 14 lipca 1983 r. o narodowym zasobie archiwalnym i archiwach (t.j. Dz.U. 2020 poz. 164), http://prawo.sejm.gov.pl/isap.nsf/download.xsp/WDU19830380173/U/ D19830173Lj.pdf [odczyt: 20.02.2010].

Ustawa z dnia 6 września 2001 r. o dostępie do informacji publicznej (Dz.U. $2001 \mathrm{nr} 112$ poz. 1198 ze zm.; t.j. Dz.U. 2016 poz. 1764), http://prawo.sejm.gov.pl/isap.nsf/DocDetails. xsp?id=WDU20011121198 [odczyt: 20.02.2010]. 